\title{
COMPARING THE COMPETITIVENESS BETWEEN BRAZILIAN AND EUROPEAN FOOTBALL (SOCCER) (G-5) -INTERPRETATIONS
} AND SUGGESTIONS

\author{
Cláudio Vicente di Gioia F. Silva \\ Faculdades IBMEC/RJ, Brazil \\ E-mail: fuzzy-consultoria@hotmail.com \\ Walter Gassenferth \\ Faculdades IBMEC/RJ, Brazil \\ E-mail: wgassenferth@timbrasil.com.br \\ Giovanna Lamastra Pacheco \\ Faculdades IBMEC/RJ, Brazil \\ E-mail: gpacheco@ibmecrj.edu.br \\ Maria Augusta Soares Machado \\ Faculdades IBMEC/RJ, Brazil \\ E-mail: mmachado@ibmecrj.br
}

\section{ABSTRACT}

Submission: $26 / 02 / 2013$

Revisions: $12 / 03 / 2013$

Accept: 24/07/2013

World sport has been seen as a growing industry, generating revenues of roughly US\$ 1 trillion a year. Playing a major role in this industry, football (soccer) is accountable for an annual turnover of approximately US\$ 250 billion - Brazil's share being approximately 1\% of that amount. The growing marketing and globalization of football has brought up new topics such as: the risks associated with competitiveness; the need for professional management; creating corporate teams; sports strategies and marketing; accounting; accountability. This paper aims at: i) understanding the risks associated with the competitiveness of football leagues; ii) comparing the competitive balance in the five largest European football markets (Germany, Spain, France, England and Italy) in relation with Brazilian football and; iii) interpreting these results in view of the literature concerning sports administration. 
Keywords: sports administration, sports strategies, sports marketing

\section{INTRODUCTION}

The concern of this paper is turned to the balance among the teams competing for the Brazilian national football championship. In that context, the more balanced the teams are, the greater the uncertainty about the results of a match (and consequently of the championship as a whole) will be. Lack of balance means not to maximize the amount of fans going to the stadiums or watching the matches on TV due to the predictability of the result. Thus, the teams and sport leagues would start incurring the risk of long-term loss of spectators, with a risk of dominance by some teams while others would go bankrupt.

Considering this broad discussion on the competitiveness in football industry, this paper gives a priority to the study of the risks of some teams concentrating wins and titles, in contrast to their opponents, which characterizes a dominance of the former over the latter and impairing the success of the championships in the long run. This paper also addresses the change in championship model as was adopted by Brazilian teams in 2003 in an attempt to "copy" the European national championships, which use the point system. The conclusions hereby, despite the short time for comparison, are also related to the selection of that system.

The main objective of this paper is comparing and interpreting the levels of competitiveness between Brazilian and European football, more specifically among the five biggest football centers in the world (England, Spain, Germany, France and Italy). The interpretation of the results will be related to the risk of dominance by some teams, bankruptcy by others, and reduced number of fans in the long term. The characteristics of the structure and management of the Brazilian football, which might influence the results achieved as well as the current point-system championship model that follows the patterns of European national championships, are also analyzed.

Table 1 illustrates the object and subject of this research, as based on Tachizawa (2002), carrying the type of organization and defined topic.

This paper makes use of secondary data and championship results disclosed by the football associations of the studied countries. It is limited to a comparison of 
the levels of competitiveness and sports balance in Brazil and in the five biggest football centers in Europe, namely: Italy, Germany, Spain, England and France.

Table 1 - Type of organization and defined topic

Subject: Sport Administration

Object: Football Industry

Title: Comparing the Competitiveness between Brazilian and European Football (Soccer) (G-5) - Interpretations and Suggestions

\begin{tabular}{|l|l|l|}
\hline Subject and Object & Type of organization & Defined topic \\
\hline $\begin{array}{l}\text { Quantitative } \\
\text { Research on Sport } \\
\text { Administration }\end{array}$ & $\begin{array}{l}\text { Brazilian football teams } \\
\text { competing in the major } \\
\text { league }\end{array}$ & $\begin{array}{l}\text { Comparing the competitiveness } \\
\text { (balance) of the five biggest European } \\
\text { championships with the Brazilian } \\
\text { championship and interpreting the } \\
\text { results }\end{array}$ \\
\hline
\end{tabular}

\section{THE FOOTBALL INDUSTRY}

World sport has been seen as a growing industry, generating revenues of roughly US\$ 1 trillion a year. Playing a major role in this industry, football (soccer) is accountable for an annual turnover of approximately US\$250 billion - Brazil's share being approximately $1 \%$ of that amount.

One way to understand the football industry lies in the typology proposed in Figure 1, which is based on Westerbeek and Smith (2003, p.89). It suggests that the sport industry is divided into three main segments, as described by Ducrey et al. (2003):

- Sporting Goods - Manufacturers of equipment, sports materials, licensed products. Examples include: Nike, Adidas and Reebok.

- Consulting - Firms providing services such as consulting, management, sport medicine, amongst others. Examples include: IMG and Octagon.

- Sports Services - Organizations offering the sport as their end product. This segment can be divided into three categories, as follows:

o The Event - Organizations that generate revenue, either directly or indirectly, from the spectators. In this category, the athletes are professional and examples of participating entities include the teams and Leagues. 
o Participants - Entities providing opportunities for people to engage in sporting activities, at a non-professional level, such as amateur teams, gymnasiums and sports communities.

o Hybrid - Organizations provide a mix of the above-mentioned categories: the event and the participants. Examples include those government agencies developing mass participation and promoting athletes who could stand out at an elite level.

Figure 1 - The Structure of the Football Industry (WESTERBEEK; SMITH, 2003). Adapted by the author.

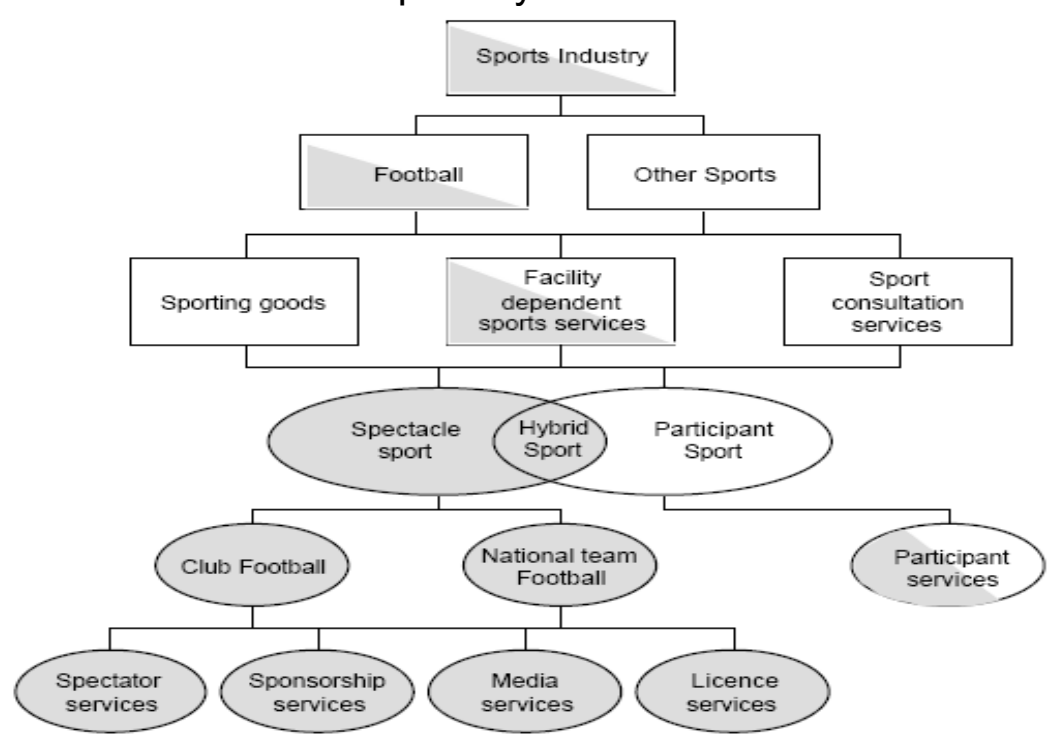

Another view of the football industry is found in Leoncini (2001) and is based on Aidar et al. (2000), which divides the structure of football as follows: i) Producer Market; ii) Consumer Market; iii) Intermediate Market (Resale and Industrial). That perspective is demonstrated in Figure 2, below.

According to this viewpoint of Aidar et al (2000), the football fans are the consumer market, who have a direct commercial relation via box office or merchandising with the Producer Market represented by the football associations. This consumer market also consumes from the Intermediate Resale Market (TV and licensed companies) and from the Intermediate Industrial Market (sports marketing companies). Lastly, the Intermediate Resale Market and the Intermediate Industrial Market interact with the Producer Market by selling broadcast rights and marketing operations, respectively. 
Figure 2: The structure of Football

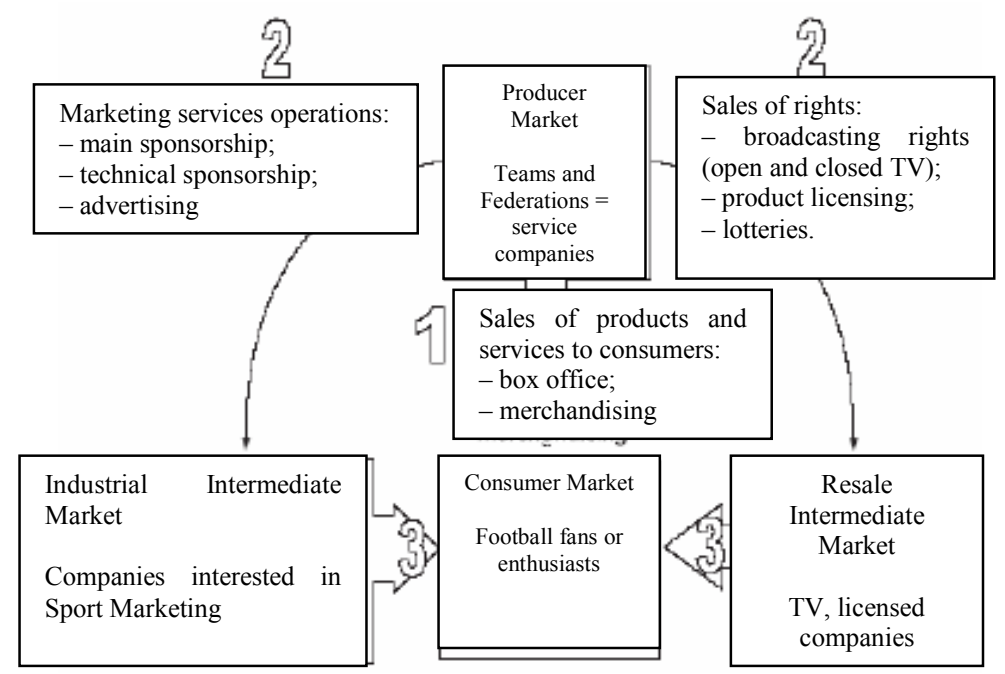

The organization of the producer market follows a world hierarchy, whereby FIFA (International Federation of Association Football) is the maximum authority in football and below it come the confederations, which accountable for football in their respective continents, as is the case of CONMEBOL (South-American Football Confederation) and UEFA (Union of European Football Associations).

Following that hierarchy, there are the national federations or confederations such as CBF (Brazilian Football Confederation), the sports leagues and the state federations, such as FERJ (Rio de Janeiro State federation), and then come the teams.

Figure 3: The Football Industry: Production Chain and Customers PRODUCTIVE CHAIN BUSINESS / CUSTOMERS CHAIN

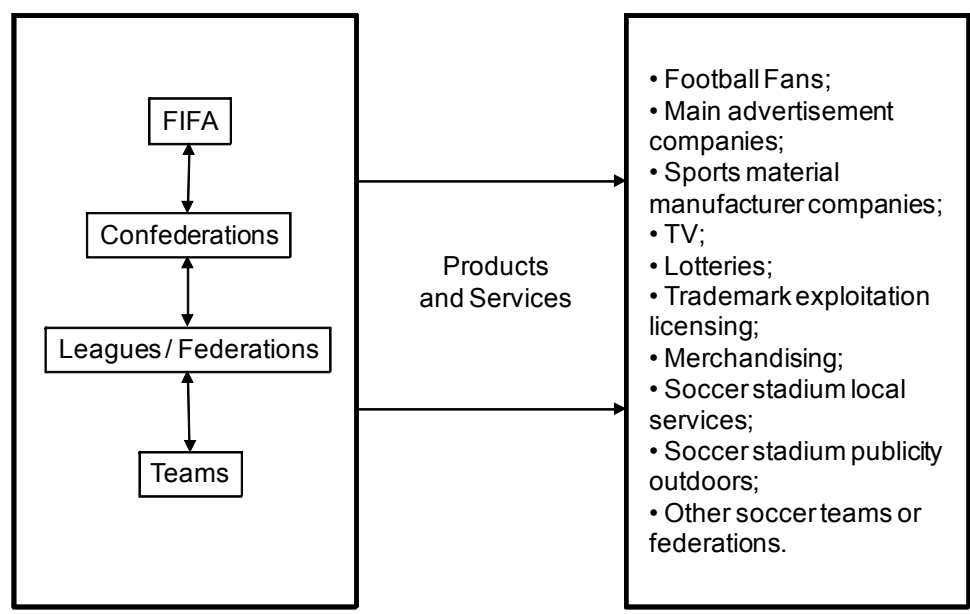

In England, there is also an attempt to classify the consumer market, the football fan, into: i) virtual fans (who do not go to the stadium); ii) local fans, who attend the matches at the stadiums in their region; iii) followers, who follow the team 
to other regions; iv) Family Supporters, who go to the stadium with another family member; and v) Corporate Supporters, those who go to the stadium and require special treatment in the cabins and VIP areas. (LEONCINI, 2001).

One of the peculiarities of this end consumer in football is that, differently from ordinary merchandise, his/her relationship with the team is lasting, despite the service it provides not being one of the best, like for example: no titles, discomfort and insecurity in the stadiums. As studied by Taylor (1998), this is an emotional relationship converted into a commercial relationship, the description of which is described in one of the best known cases in football, the team Manchester United. Since the team had a higher reputation than the other English teams, it was a leader in terms of the average public attending its matches even when it failed to win titles (SZYMANSKY 1995). In Brazil, the football teams manage to narrow the relationship with the fans even being relegated to the second division in the league, as is the case of Botafogo, in Rio de Janeiro, or even down to the third division, like Fluminense, also in Rio.

That customer-team relationship suggests that football demand is inflexible in relation to price (SZYMANSKY; KUYPERS, 1999). Nonetheless, in Brazil, such inflexibility appears to be discussable as the teams fail to achieve better revenues at the box offices due to price increase. One factor that might contribute to such inflexibility is that football is competitor in the entertainment industry, which provides the society with other alternatives (such as the cinema, theater, music shows, and other sports), and the Brazilian society has demonstrated some dissatisfaction with the level of the service provided in the sports events. That fact demonstrates as a strategic error in running the business, as described by Porter (1998, p.26), that: "Many managers concentrate exclusively on their direct antagonists in the fight for market share and go unnoticing that they too are competing against their customers and suppliers for bargain power. Meanwhile, they also neglect the attention to the newcomers or fail to recognize the subtle threat of substituting products."

Still regarding end customers, according to Ducrey et al. (2003), the most important factors for the fans are as follows: 
- The quality of the match - This has to do with aspects of the show, entertainment, the pleasure to watch the matches and the quality of the visiting teams.

- Uncertainty, or unpredictability of the result (of the match or championship) Regarding the uncertainty of a match, generally, the tighter the result expected for a match, the more that match is attracting to the fans. As to the result of a championship, understanding goes that the average attendance is influenced by the dispute and that the higher the competitive balance, more teams have a chance to win the title. Consequently, the fans consume more as a response to such fierce competition, thus increasing the commercial activities related to the championship and the teams.

- The success of that fan's team - There is a level of satisfaction in those fans which is achieved by the team's good performance. Teams that constantly lose are less attractive to the public.

Michael Porter (1986) asserts that, in order to reach a defendable position in the market, the companies can use three types of generic strategies to always lead some sort of market. One such strategy proposes leadership of one market niche, if it is not possible to lead the market as a whole, by total cost or by product differentiation. Therefore, the incentive to leadership and the possibility to it ensure greater competitiveness in the industry. According to the championship models of the major European centers, there is an option to lead niches - one example refers to the intermediate leaders that qualify for a the UEFA Cup or for the Champions Cup or to lead the championship as a whole or the lower block in the standing, which ensures the team to remain in the first division championship for another year. That model, which encourages neache leaderships, makes the tournament more attracting even for the fans of those teams that cannot lead the championship as a whole.

Another perspective on the structure of football shows that the performance of a team can be understood by the characteristics of the industry (structure and behavior) and by that team's strategy (LEONCINI, 2001). This analysis was performed by Szymansky \& Kuypers (1999), who identified critical factors that could explain the logic of the football business, namely: i) Sport Performance - the team's performance in the championship; ii) Operating Profit - The difference between the 
revenues generated by the team and its overall expenses before Income Tax; iii) Salary Expenditures - The expenditures on salaries, especially those of the technical department (players, coaches, trainers, etc.); iv) The Result from Player Transfer the financial income from the operations in the players market.

Despite a proven relation between performance in the field and financial performance does not exist, such factors would indeed making up the basis for two relationships studied in the definition of a football team's strategic management scope, namely: i) salary expenditures $\mathrm{x}$ performance in the field; ii) performance in the field $x$ generated revenues (LEONCINI, 2001).

According to Dell'Osso and Symanski (1991), salary expenditures might have a direct relationship with the performance in the field. However, the expenditures on high wages also represent a threat to the financial balance of the teams, thus making that equation more difficult to be solved. An aggravating factor is that one team may invest in great players for a short-term performance, win titles and yet have losses in the end of the fiscal period. In Europe, specifically in the English football, the concern with that threat of the high wages is visible in the administration reports of the teams, as is the case of the 2003 annual report of Liverpool: "As we see it, the team continues to exercise careful control over the costs related to the wages paid to the players". (Authors' Translation)

Lastly, it is possible to analyze the football industry through its sources of revenue, as per Leoncini (2001), whereby the most common commercial relationships for Italian/English leagues and teams can be classified on the basis of the following types of revenue: i) the relationship with TV (transmission rights); ii) the relationship with the main sponsor; iii) the relationship with the Lotteries; iv) the relationship with the fan (box office/merchandising); v) the relationship with the technical sponsor; vi) the relationship with merchandise producing companies (operating the brand via licensing / advertising signs); vii) the relationship with other teams / federations (trade of players).

This paper makes use of the classification of the revenue sources described in the reports of the richest teams in the world in terms of revenue by DELOITTE \& TOUCHE, namely: i) Commercial, which is divided into a) Merchandising and Licensing; b) Sponsorship and Supply of sport material; ii) Box office; iii) The Media. 
The comparative analysis between the sources of revenue of European teams and the Brazilian teams is included in section 3.2.4 on Brazilian football.

\section{METHODOLOGY}

The research on competitive balance was firstly conducted on the basis of what the literature on industrial economics and the economic regulation presents as industrial concentration measures. These are measures demonstrate, ex-post, what can be regarded as a dominating position or even, in terms of regulation, as a market power a company holds in view of its competitors. Such industrial concentration measures include the concentration ratios and especially the Herfindahl-Hirschmann Index $(\mathrm{HHI})$ as an indicator that is also used in the analyses of the concentration actions by economic regulation agencies such as the US Federal Trade Commission.

Concerning the specific research on competitive balance, the work of Oughton \& Michie (2004) summarizes the main techniques used in sports leagues. Such measures are listed in Table 2 of the Appendix to this paper. In the specific case of the competitive balance in football, item "b" of Table 2 shows the different papers addressing this sport which are classified in accordance with the objectives of the research, such as: i) long-term dominance, ii) seasonal; iii) match.

In the analyses of the papers on the balance in football and sport leagues, the $\mathrm{HHI}$ is observed to be used both for long-term dominance concerns and seasonally, which is in accordance with the delimitation of the proposed study. Thus, in view of the acceptance of this indicator as a measure of concentration as well as in the publications about sports leagues and football, this paper is intended for calculating the results of the five largest European football markets (Germany, Spain, France, England and Italy), having the $\mathrm{HHI}$ as a measure of analysis.

The time period to be studied is ten years, considering the difficulties to obtain the figures for the Brazilian Championship before that period of time due to the different formats the teams used.

In this setting, two problems become relevant for the research and are presented below and solved in section presenting the two calculations to be used.

i) The changes in the championship model for the Major League ('A' Series) of the Brazilian Championship 
Before 2003, the model adopted in the Brazilian Championship was known as qualifying phase model. After (and including) 2003, the point system model was selected. Thus, like in 2002, for example, the first eight teams of the first phase of the tournament would qualify for the second phase. This means that a given team could have more points, or better performance, throughout the championship and not be the champion, since the advantages achieved in the first phase could be lost in the second phase. Moreover, some teams (those classifying for the next phase) ended up playing more matches than others (which would not classify), thus impairing the calculations.

ii) The amount of teams competing in the championships

Both in Europe and in Brazil there are cases whereby the amount of competing teams varies from year to year within the historical sequence to be studied. Also, the number of teams that vie in the tournament varies from country to country.

These problems are solved below in the demonstration of the two types of calculations.

\section{- Calculation 1: HHI - Oughton \& Michie (2004) Model - Seasonal}

This calculation is used in papers such as that of Oughton \& Michie (2004), and also used by Depkin (1999), by calculating the $\mathrm{HHI}$ on the classification table and the performance in percentage for each team. For demonstration purposes, the table below describes the $\mathrm{HHI}$, for the example of the maximum unbalance possible, for 20 teams.

The calculation is done on the performance of each team in the championship and by the sums of the squares of that performance, as per the formula below, whereby $\mathrm{Si}$ is the performance of each team in relation to the potential maximum points total:

$$
H H I=\sum_{i=1}^{n} s_{i}^{2}
$$


Table 2: Teams Performances and Maximum HHI

\begin{tabular}{|c|c|c|c|c|c|c|c|}
\hline TEAMS & MATCHES & WINS & PPG & TOTAL & MAXIMUM & PERFORMANCE (\%) & (PERFORMANCE) $^{2}$ \\
\hline 1 & 38 & 38 & 3 & 114 & 114 & $100 \%$ & 1.000 \\
\hline 2 & 38 & 36 & 3 & 108 & 114 & $95 \%$ & 0.898 \\
\hline 3 & 38 & 34 & 3 & 102 & 114 & $89 \%$ & 0.801 \\
\hline 4 & 38 & 32 & 3 & 96 & 114 & $84 \%$ & 0.709 \\
\hline 5 & 38 & 30 & 3 & 90 & 114 & $79 \%$ & 0.623 \\
\hline 6 & 38 & 28 & 3 & 84 & 114 & $74 \%$ & 0.543 \\
\hline 7 & 38 & 26 & 3 & 78 & 114 & $68 \%$ & 0.468 \\
\hline 8 & 38 & 24 & 3 & 72 & 114 & $63 \%$ & 0.399 \\
\hline 9 & 38 & 22 & 3 & 66 & 114 & $58 \%$ & 0.335 \\
\hline 10 & 38 & 20 & 3 & 60 & 114 & $53 \%$ & 0.277 \\
\hline 11 & 38 & 18 & 3 & 54 & 114 & $47 \%$ & 0.224 \\
\hline 12 & 38 & 16 & 3 & 48 & 114 & $42 \%$ & 0.177 \\
\hline 13 & 38 & 14 & 3 & 42 & 114 & $37 \%$ & 0.136 \\
\hline 14 & 38 & 12 & 3 & 36 & 114 & $32 \%$ & 0.100 \\
\hline 15 & 38 & 10 & 3 & 30 & 114 & $26 \%$ & 0.069 \\
\hline 16 & 38 & 8 & 3 & 24 & 114 & $21 \%$ & 0.044 \\
\hline 17 & 38 & 6 & 3 & 18 & 114 & $16 \%$ & 0.025 \\
\hline 18 & 38 & 4 & 3 & 12 & 114 & $11 \%$ & 0.011 \\
\hline 19 & 38 & 2 & 3 & 6 & 114 & $5 \%$ & 0.003 \\
\hline 20 & 38 & 0 & 3 & 0 & 114 & $0 \%$ & 0.000 \\
\hline & & & & & & BASIS & 6.842 \\
\hline & & & & & & HHI (MAXIMUM) & 0.068 \\
\hline
\end{tabular}

PPG - Points per game

The table below shows that maximum and minimum $\mathrm{HHI}$ in accordance with the number of teams competing in the championship. Thus, in the case of a 20-team championship, if the $\mathrm{HHI}$ calculation reaches, for instance, "0.4789" in a given year, it means that for that particular year the $\mathrm{HHI}$ is $70 \%$ from the maximum $\mathrm{HHI}$, that is, from the maximum unbalance, which in that case would be "0.0684". Thus, problem "ii" above, with relation to the number of teams competing in the championship, would be solved since using a percentage of the maximum $\mathrm{HHI}$ would act as a standard setter is independent from the number of teams.

Table 3: Maximum and Minimum HHI.

\begin{tabular}{|c|c|r|r|}
\hline TEAMS & MATCHES & MAX HHI & MIN HHI \\
\hline \hline 18 & 17 or 34 & 0.0684 & 0.0222 \\
\hline 20 & 19 or 38 & 0.0684 & 0.0222 \\
\hline 22 & 21 or 42 & 0.0751 & 0.0244 \\
\hline 24 & 23 or 46 & 0.0817 & 0.0267 \\
\hline 25 & 24 or 48 & 0.0851 & 0.0278 \\
\hline 26 & 25 or 50 & 0.0884 & 0.0289 \\
\hline 28 & 27 or 54 & 0.0951 & 0.0311 \\
\hline
\end{tabular}

- For calculating the HHI Max, it does not matter whether the format is for one shift (one leg) or double shift (two legs). 
This way, it will be possible to calculate, for the five largest European championships and for the Brazilian championship, a history for those ten years in relation to the maximum $\mathrm{HHI}$ and a trend curve, thus allowing for comparing the Brazilian competitive balance in relation to the other championships.

Moreover, in order to avoid problems regarding the amount of matches to be played, in the case of Brazil, for the years in which the championship did not follow the points system (before 2003), data corresponding only to the first phase (the qualifying phase) will be used.

Yet, despite being one of the best indicators for comparison, using such data means assuming problem " $\mathrm{i}$ " presented above, whereby the champion may not have the best performance of all teams in the tournament, in the case of the Brazilian championship before 2003. This problem shall be offset in calculation "2" herein.

- Calculation 2: Model of Dell'Osso. F \& Symanski, S (1991)

This paper also uses the measure proposed by Dell'Osso. F \& Symanski, S (1991), included in the paper 'Who Are the Champions?', as a simple calculation to supplement the previous analysis by granting 1,2 and 3 points for first, second and third places in the championship, respectively, and by verifying the concentration of the same teams in the first positions in the championship, thus representing a longterm dominance.

This methodology shall be complemented by using the $\mathrm{HHI}$ in order for us to demonstrate the concentration of such teams in the first positions of the tournaments over a period of time, in this case, ten years. This methodology is based on Gerrad (2004) and Eckard (2001) for long-term dominance.

Also, for this calculation, the figures achieved with the maximum $\mathrm{HHI}$ are compared. In that case, the "Maximum HHI" represents the maximum concentration of times in the first three positions, representing the most unbalance possible, as shown next.

The comparison of this "maximum HHl" (example 1) will be made against another more balanced situation (example 2). In example 2, the historical $\mathrm{HHI}$ for the ten-year period studied accounts for only $32 \%$ of the Maximum $\mathrm{HHI}$, which would represent the maximum unbalance. 
Example 1:

\begin{tabular}{|c|c|c|c|c|c|c|c|c|c|c|c|c|c|}
\hline COUNTRY & $\mathbf{2 0 0 5}$ & $\mathbf{2 0 0 4}$ & $\mathbf{2 0 0 3}$ & $\mathbf{2 0 0 2}$ & $\mathbf{2 0 0 1}$ & $\mathbf{2 0 0 0}$ & $\mathbf{1 9 9 9}$ & $\mathbf{1 9 9 8}$ & $\mathbf{1 9 9 7}$ & $\mathbf{1 9 9 6}$ & TOTAL & $\mathbf{\%}$ & HHI MAX \\
\hline \hline Team A & 3 & 3 & 3 & 3 & 3 & 3 & 3 & 3 & 3 & 3 & 30 & $50 \%$ & 2500 \\
\hline Team B & 2 & 2 & 2 & 2 & 2 & 2 & 2 & 2 & 2 & 2 & 20 & $33 \%$ & 1111 \\
\hline Team C & 1 & 1 & 1 & 1 & 1 & 1 & 1 & 1 & 1 & 1 & 10 & $17 \%$ & 278 \\
\hline
\end{tabular}

Champion: 3 points; Vice Champion: 2 points; Third place: 1 point.

Example 2:

\begin{tabular}{|c|c|c|c|c|c|c|c|c|c|c|c|c|c|}
\hline COUNTRY & $\mathbf{2 0 0 5}$ & $\mathbf{2 0 0 4}$ & $\mathbf{2 0 0 3}$ & $\mathbf{2 0 0 2}$ & $\mathbf{2 0 0 1}$ & $\mathbf{2 0 0 0}$ & $\mathbf{1 9 9 9}$ & $\mathbf{1 9 9 8}$ & $\mathbf{1 9 9 7}$ & $\mathbf{1 9 9 6}$ & TOTAL & $\mathbf{\%}$ & HHI \\
\hline \hline Team A & 3 & 3 & 3 & 2 & 2 & 2 & 1 & 1 & 1 & 1 & 19 & $32 \%$ & 1003 \\
\hline Team B & 2 & 2 & 2 & 1 & 1 & 1 & 0 & 0 & 0 & 0 & 9 & $15 \%$ & 225 \\
\hline Team C & 1 & 1 & 1 & 0 & 0 & 0 & 0 & 0 & 0 & 0 & 3 & $5 \%$ & 25 \\
\hline Team D & 0 & 0 & 0 & 3 & 3 & 3 & 2 & 2 & 2 & 2 & 17 & $28 \%$ & 803 \\
\hline Team E & 0 & 0 & 0 & 0 & 0 & 0 & 3 & 3 & 3 & 3 & 12 & $20 \%$ & 400 \\
\hline
\end{tabular}

Champion: 3 points; Vice Champion: 2 points; Third place: 1 point.

This way, it will be possible to calculate this figure for the five largest European championships and for the Brazilian championship around a figure that analyzes the concentration difference of the same teams in the first divisions. This becomes an effective measure of long-term dominance.

Moreover, complementing calculation " 1 " proposed above, this becomes a way to solve problem "i", in such a way that the first places in the final classification are those acting as the basis for comparison..

\section{RESULTS}

The results for the studies are demonstrated as per the two calculations described in the methodology. The first of them is based on the model of Oughton \& Michie (2004) and on other works such as that of Depkin (1999) for determining the seasonal competitive balance. The second is based on authors such as Dell'Osso. $F$ \& Symanski, S (1991), Gerrad (2004) and Eckard (2001) for long-term dominance. The interpretations on the results and the comments about other sports and about future researches are presented next.

\section{a. SEASONAL CALCULATION}

The seasonal calculation considered the annual classification for each championship for the 10-year period. Firstly, the data for each country are presented - such data being calculated on a yearly basis and compared with the maximum unbalance possible for the number of teams competing in the tournament. These data are presented as a table in section a.1. 
Next, the graphs with the curves are presented. Firstly, the graphs are related to that maximum unbalance and, secondly, they are related to the trend curve in logarithms of the previous graph. These data are presented in section a.2.

\section{a. 1 Tables.}

\begin{tabular}{|c|c|c|c|c|c|c|}
\hline \multirow{2}{*}{\multicolumn{3}{|c|}{$\begin{array}{l}\text { Brazilian Championship } \\
\text { Season teams matches }\end{array}$}} & \multicolumn{3}{|c|}{ H INDEX } & \multirow{3}{*}{$\frac{\% \text { Max Unbal. Brazi }}{64.9 \%}$} \\
\hline & & & Max & Min & Brazilian Index & \\
\hline 200 & 22 & 42 & 0.0751 & 0.0244 & 0.0487 & \\
\hline 200 & 24 & 48 & 0.0817 & 0.0267 & 0.0508 & $62.1 \%$ \\
\hline 200 & 24 & 48 & 0.0817 & 0.0267 & 0.0524 & $64.2 \%$ \\
\hline 200 & 26 & 25 & 0.0884 & 0.0289 & 0.0582 & $65.9 \%$ \\
\hline 200 & 28 & 27 & 0.0951 & 0.0311 & 0.0632 & $66.5 \%$ \\
\hline 200 & 25 & 24 & 0.0851 & 0.0278 & 0.0552 & $64.9 \%$ \\
\hline 199 & 22 & 21 & 0.0751 & 0.0222 & 0.0471 & $62.8 \%$ \\
\hline 199 & 24 & 23 & 0.0817 & 0.0267 & 0.0534 & $65.4 \%$ \\
\hline 199 & 26 & 25 & 0.0884 & 0.0289 & 0.0561 & $63.4 \%$ \\
\hline 199 & 24 & 23 & 0.0817 & 0.0267 & 0.0529 & $64.7 \%$ \\
\hline
\end{tabular}

\begin{tabular}{|c|c|c|c|c|c|c|}
\hline \multicolumn{3}{|c|}{ English Championship } & \multicolumn{3}{|c|}{ H INDEX } & \multirow[b]{2}{*}{ \% Max Unbal. Eng. } \\
\hline Season & teams & matches & $\operatorname{Max}$ & \begin{tabular}{|l|}
$\operatorname{Min}$ \\
\end{tabular} & England Index & \\
\hline $2005 / 06$ & 20 & 38 & 0.0684 & 0.0222 & 0.0485 & $70.9 \%$ \\
\hline $2004 / 05$ & 20 & 38 & 0.0684 & 0.0222 & 0.0451 & $65.9 \%$ \\
\hline $2003 / 04$ & 20 & 38 & 0.0684 & 0.0222 & 0.0443 & $64.8 \%$ \\
\hline $2002 / 03$ & 20 & 38 & 0.0684 & 0.0222 & 0.0458 & $67.0 \%$ \\
\hline $2001 / 02$ & 20 & 38 & 0.0684 & 0.0222 & 0.0456 & $66.7 \%$ \\
\hline $2000 / 01$ & 20 & 38 & 0.0684 & 0.0222 & 0.0444 & $64.9 \%$ \\
\hline $1999 / 00$ & 20 & 38 & 0.0684 & 0.0222 & 0.0460 & $67.3 \%$ \\
\hline $1998 / 99$ & 20 & 38 & 0.0684 & 0.0222 & 0.0433 & $63.3 \%$ \\
\hline $1997 / 98$ & 20 & 38 & 0.0684 & 0.0222 & 0.0443 & $64.7 \%$ \\
\hline $1996 / 97$ & 20 & 38 & 0.0684 & 0.0222 & 0.0422 & $61.6 \%$ \\
\hline
\end{tabular}

\begin{tabular}{|c|c|c|c|c|c|c|}
\hline \multicolumn{3}{|c|}{ Italian Championship } & \multicolumn{3}{|c|}{ H INDEX } & \multirow[b]{2}{*}{$\%$ Max Unbal. Italy } \\
\hline Season & teams & matches & $\operatorname{Max}$ & Min & Italian Idex & \\
\hline $2005 / 06$ & 20 & 38 & 0.0684 & 0.0222 & 0.0464 & $67.8 \%$ \\
\hline $2004 / 05$ & 20 & 38 & 0.0684 & 0.0222 & 0.0425 & $62.1 \%$ \\
\hline $2003 / 04$ & 18 & 34 & 0.0618 & 0.0200 & 0.0416 & $67.3 \%$ \\
\hline $2002 / 03$ & 18 & 34 & 0.0618 & 0.0200 & 0.0397 & $64.3 \%$ \\
\hline $2001 / 02$ & 18 & 34 & 0.0618 & 0.0200 & 0.0405 & $65.6 \%$ \\
\hline $2000 / 01$ & 18 & 34 & 0.0618 & 0.0200 & 0.0401 & $64.9 \%$ \\
\hline $1999 / 00$ & 18 & 34 & 0.0618 & 0.0200 & 0.0399 & $64.6 \%$ \\
\hline 1998 / 99 & 18 & 34 & 0.0618 & 0.0200 & 0.0398 & $64.5 \%$ \\
\hline $1997 / 98$ & 18 & 34 & 0.0618 & 0.0200 & 0.0409 & $66.3 \%$ \\
\hline $1996 / 97$ & 18 & 34 & 0.0618 & 0.0200 & 0.0379 & $61.3 \%$ \\
\hline
\end{tabular}

\begin{tabular}{|c|c|c|c|c|c|c|}
\hline \multicolumn{3}{|c|}{ Spanish Championship } & \multicolumn{3}{|c|}{ H INDEX } & \multirow{3}{*}{$\frac{\% \text { Max Unbal. Spain }}{64.8 \%}$} \\
\hline Season & teams & matches & $\operatorname{Max}$ & Min & Spain Index & \\
\hline $2005 / 06$ & 20 & 38 & 0.0684 & 0.0222 & 0.0444 & \\
\hline $2004 / 05$ & 20 & 38 & 0.0684 & 0.0222 & 0.0446 & $65.2 \%$ \\
\hline $2003 / 04$ & 20 & 38 & 0.0684 & 0.0222 & 0.0446 & $65.1 \%$ \\
\hline $2002 / 03$ & 20 & 38 & 0.0684 & 0.0222 & 0.0443 & $64.7 \%$ \\
\hline $2001 / 02$ & 20 & 38 & 0.0684 & 0.0222 & 0.0432 & $63.1 \%$ \\
\hline $2000 / 01$ & 20 & 38 & 0.0684 & 0.0222 & 0.0440 & $64.3 \%$ \\
\hline $1999 / 00$ & 20 & 38 & 0.0684 & 0.0222 & 0.0422 & $61.6 \%$ \\
\hline $1998 / 99$ & 20 & 38 & 0.0684 & 0.0222 & 0.0446 & $65.1 \%$ \\
\hline & 20 & 38 & 0.0684 & 0.0222 & 0.0433 & $63.3 \%$ \\
\hline 1996 / 97 & 22 & 42 & 0.0751 & 0.0244 & 0.0492 & $65.5 \%$ \\
\hline
\end{tabular}

German Championship

\begin{tabular}{|c|c|c|c|}
\hline \multicolumn{3}{|c|}{ H INDEX } & \\
\hline Max & Min & Germany Index & $\begin{array}{c}\text { \% Max Unbal. } \\
\text { Germany }\end{array}$ \\
\hline 0.0618 & 0.0200 & 0.0394 & $63.8 \%$ \\
0.0618 & 0.0200 & 0.0420 & $68.0 \%$ \\
0.0618 & 0.0200 & 0.0415 & $67.1 \%$ \\
0.0618 & 0.0200 & 0.0398 & $64.4 \%$ \\
0.0618 & 0.0200 & 0.0423 & $68.5 \%$ \\
0.0618 & 0.0200 & 0.0402 & $65.1 \%$ \\
0.0618 & 0.0200 & 0.0397 & $64.2 \%$ \\
0.0618 & 0.0200 & 0.0400 & $64.8 \%$ \\
0.0618 & 0.0200 & 0.0386 & $62.5 \%$ \\
0.0618 & 0.0200 & 0.0410 & $66.3 \%$ \\
\hline
\end{tabular}

\begin{tabular}{|c|c|c|c|c|c|c|}
\hline \multicolumn{3}{|c|}{ French Championship } & \multicolumn{3}{|c|}{ H INDEX } & \multirow[b]{2}{*}{$\begin{array}{c}\text { \% Max Unbal } \\
\text { France }\end{array}$} \\
\hline Season & \multicolumn{2}{|c|}{ teams matches } & $\operatorname{Max}$ & Min & France Index & \\
\hline $2005 / 06$ & 20 & 38 & 0.0684 & 0.0222 & 0.0429 & $62.7 \%$ \\
\hline $2004 / 05$ & 20 & 38 & 0.0684 & 0.0222 & 0.0406 & $59.4 \%$ \\
\hline $2003 / 04$ & 20 & 38 & 0.0684 & 0.0222 & 0.0446 & $65.1 \%$ \\
\hline $2002 / 03$ & 20 & 38 & 0.0684 & 0.0222 & 0.0433 & $63.2 \%$ \\
\hline $2001 / 02$ & 18 & 34 & 0.0618 & 0.0200 & 0.0388 & $62.7 \%$ \\
\hline $2000 / 01$ & 18 & 34 & 0.0618 & 0.0200 & 0.0390 & $63.1 \%$ \\
\hline $1999 / 00$ & 18 & 34 & 0.0618 & 0.0200 & 0.0386 & $62.4 \%$ \\
\hline $1998 / 99$ & 18 & 34 & 0.0618 & 0.0200 & 0.0397 & $64.2 \%$ \\
\hline $1997 / 98$ & 18 & 34 & 0.0618 & 0.0200 & 0.0401 & $65.0 \%$ \\
\hline $1996 / 97$ & 20 & 38 & 0.0684 & 0.0222 & 0.0431 & $63.0 \%$ \\
\hline
\end{tabular}

a. 2 Graphs.
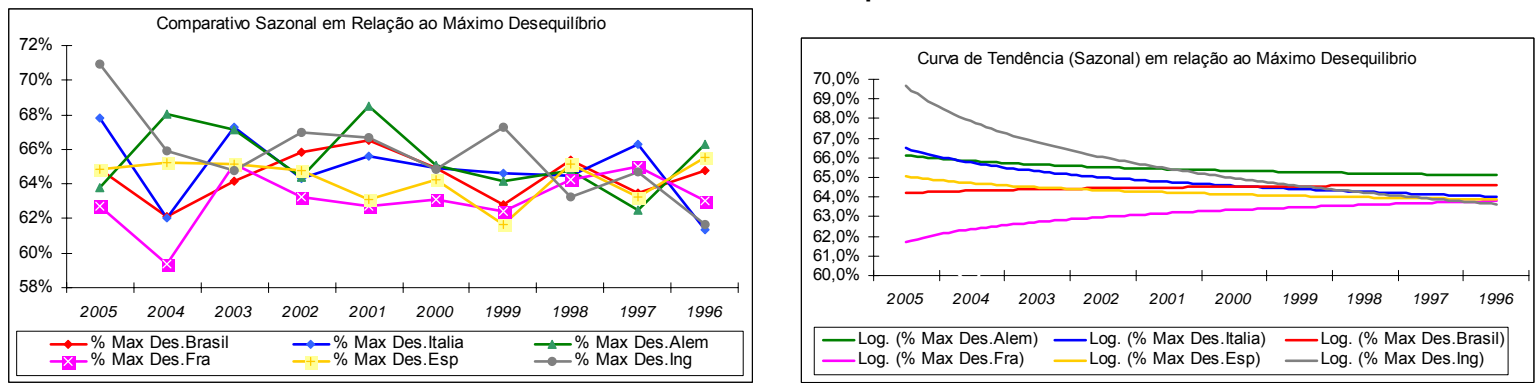

\section{b. DOMINANCE CALCULATION}

The dominance calculation considered the final positions of the yearly classifications. From them, the concentration of the same teams in leading positions (first, second and third place) was calculated by using the $\mathrm{HHI}$ concentration indicator for the 10-year period and through a comparison amongst the various national championships.

The tables below show the calculations by National Championship and, next, a table is presented in order of unbalance, which summarizes the data presented. 
ISSN: 2236-269X

DOI: 10.14807/ijmp.v4i2.123

b. 1 Tables.

\begin{tabular}{|c|c|c|c|c|c|c|c|c|c|c|c|c|c|c|}
\hline BRAZIL & $\mathbf{2 0 0 5}$ & $\mathbf{2 0 0 4}$ & $\mathbf{2 0 0 3}$ & $\mathbf{2 0 0 2}$ & $\mathbf{2 0 0 1}$ & $\mathbf{2 0 0 0}$ & $\mathbf{1 9 9 9}$ & $\mathbf{1 9 9 8}$ & $\mathbf{1 9 9 7}$ & $\mathbf{1 9 9 6}$ & TOTAL & $\%$ & HHI & \% HHI MAX \\
\hline \hline Corínthians & 3 & & & 2 & & & 3 & 3 & & & 11 & $18 \%$ & 336.1 \\
\hline Santos & & 3 & 2 & 3 & & & & 1 & & & 9 & $15 \%$ & 225.0 \\
\hline Cruzeiro & & & 3 & & & 1 & & 2 & & & 6 & $10 \%$ & 100.0 \\
\hline Vasco & & & & & & 3 & & & 3 & & 6 & $10 \%$ & 100.0 \\
\hline Atlético PR & & 2 & & & 3 & & & & & & 5 & $8 \%$ & 69.4 \\
\hline Grêmio & & & & 1 & & & & & & 3 & 4 & $7 \%$ & 44.4 \\
\hline S.Caetano & & & & & 2 & 2 & & & & & 4 & $7 \%$ & 44.4 \\
\hline São Paulo & & 1 & 1 & & & & 1 & & & & 3 & $5 \%$ & 25.0 \\
\hline Atlético MG & & & & & & & 2 & & & 1 & 3 & $5 \%$ & 25.0 \\
\hline Internacional & 2 & & & & & & & & 1 & & 3 & $5 \%$ & 25.0 \\
\hline Palmeiras & & & & & & & & & 2 & & 2 & $3 \%$ & 11.1 \\
\hline Portuguesa & & & & & & & & & & 2 & 2 & $3 \%$ & 11.1 \\
\hline Fluminense & & & & & 1 & & & & & & 1 & $2 \%$ & 2.8 \\
\hline Goías & 1 & & & & & & & & & & 1 & $2 \%$ & 2.8 & \\
\hline
\end{tabular}

\begin{tabular}{|c|c|c|c|c|c|c|c|c|c|c|c|c|c|c|}
\hline ENGLAND & $\mathbf{2 0 0 5}$ & $\mathbf{2 0 0 4}$ & $\mathbf{2 0 0 3}$ & $\mathbf{2 0 0 2}$ & $\mathbf{2 0 0 1}$ & $\mathbf{2 0 0 0}$ & $\mathbf{1 9 9 9}$ & $\mathbf{1 9 9 8}$ & $\mathbf{1 9 9 7}$ & $\mathbf{1 9 9 6}$ & TOTAL & $\mathbf{\%}$ & HHI & \% HHI MAX \\
\hline \hline Chelsea & 3 & 3 & 2 & & & & & 1 & & & 9 & $15 \%$ & 225.0 \\
\hline Manchester & 2 & 1 & 1 & 3 & 1 & 3 & 3 & 3 & 2 & 3 & 22 & $37 \%$ & 1344.4 \\
\hline Arsenal & & 2 & 3 & 2 & 3 & 2 & 2 & 2 & 3 & 1 & 20 & $33 \%$ & 1111.1 \\
\hline Liverpool & 1 & & & & 2 & 1 & & & 1 & & 5 & $8 \%$ & 69.4 \\
\hline Leeds & & & & & & & 1 & & & & 1 & $2 \%$ & 2.8 \\
\hline New Castle & & & & 1 & & & & & & 2 & 3 & $5 \%$ & 25.0 & \\
\hline
\end{tabular}

\begin{tabular}{|c|c|c|c|c|c|c|c|c|c|c|c|c|c|c|}
\hline SPAIN & $\mathbf{2 0 0 5}$ & $\mathbf{2 0 0 4}$ & $\mathbf{2 0 0 3}$ & $\mathbf{2 0 0 2}$ & $\mathbf{2 0 0 1}$ & $\mathbf{2 0 0 0}$ & $\mathbf{1 9 9 9}$ & $\mathbf{1 9 9 8}$ & $\mathbf{1 9 9 7}$ & $\mathbf{1 9 9 6}$ & TOTAL & $\mathbf{\%}$ & HHI & \% HHI MAX \\
\hline \hline Barcelona & 3 & 3 & 2 & & & & 2 & 3 & 3 & 2 & 18 & $30 \%$ & 900.0 & \\
\hline Valencia & 1 & & 3 & & 3 & & 1 & & & & 8 & $13 \%$ & 177.8 \\
\hline Real Madrid & 2 & 2 & & 3 & 1 & 3 & & 2 & & 3 & 16 & $27 \%$ & 711.1 \\
\hline Deportivo & & & 1 & 1 & 2 & 2 & 3 & & & & 9 & $15 \%$ & 225.0 \\
\hline Villareal & & 1 & & & & & & & & & 1 & $2 \%$ & 2.8 \\
\hline Real Sociedad & & & & 2 & & & & & 1 & & 3 & $5 \%$ & 25.0 \\
\hline Mallorca & & & & & & 1 & & 1 & & & 2 & $3 \%$ & 11.1 \\
\hline Atletico Bilbao & & & & & & & & & 2 & & 2 & $3 \%$ & 11.1 \\
\hline Sevilla & & & & & & & & & & 1 & 1 & $2 \%$ & 2.8 & \\
\hline
\end{tabular}

\begin{tabular}{|c|c|c|c|c|c|c|c|c|c|c|c|c|c|c|}
\hline ITALY & $\mathbf{2 0 0 5}$ & $\mathbf{2 0 0 4}$ & $\mathbf{2 0 0 3}$ & $\mathbf{2 0 0 2}$ & $\mathbf{2 0 0 1}$ & $\mathbf{2 0 0 0}$ & $\mathbf{1 9 9 9}$ & $\mathbf{1 9 9 8}$ & $\mathbf{1 9 9 7}$ & $\mathbf{1 9 9 6}$ & TOTAL & $\mathbf{\%}$ & HHI & $\%$ HHI MAX \\
\hline \hline Juventus & 3 & 3 & 1 & 3 & 3 & 2 & 2 & & 3 & 3 & 23 & $38 \%$ & 1469.4 \\
\hline Milan & 2 & 2 & 3 & 1 & & & 1 & 3 & & & 12 & $20 \%$ & 400.0 \\
\hline Roma & & & 2 & & 2 & 3 & & & & & 7 & $12 \%$ & 136.1 \\
\hline Lazio & & & & & & 1 & 3 & 2 & & & 6 & $10 \%$ & 100.0 \\
\hline Inter Milano & 1 & 1 & & 2 & 1 & & & & 2 & 1 & 8 & $13 \%$ & 177.8 \\
\hline Fiorentina & & & & & & & & 1 & & & 1 & $2 \%$ & 2.8 \\
\hline Udinese & & & & & & & & & 1 & & 1 & $2 \%$ & 2.8 \\
\hline Parma & & & & & & & & & 2 & 2 & $3 \%$ & 11.1 & \\
\hline
\end{tabular}

\begin{tabular}{|c|c|c|c|c|c|c|c|c|c|c|c|c|c|c|}
\hline GERMANY & $\mathbf{2 0 0 5}$ & $\mathbf{2 0 0 4}$ & $\mathbf{2 0 0 3}$ & $\mathbf{2 0 0 2}$ & $\mathbf{2 0 0 1}$ & $\mathbf{2 0 0 0}$ & $\mathbf{1 9 9 9}$ & $\mathbf{1 9 9 8}$ & $\mathbf{1 9 9 7}$ & $\mathbf{1 9 9 6}$ & TOTAL & $\mathbf{\%}$ & HHI & $\% \mathrm{HHI}$ MAX \\
\hline \hline Bayern München & 3 & 3 & 2 & 3 & 1 & 3 & 3 & 3 & 2 & 3 & 26 & $43 \%$ & 1877.8 & \\
\hline Werder Bremen & 2 & 1 & 3 & & & & & & & & 6 & $10 \%$ & 100.0 \\
\hline Borussia & & & & 1 & 3 & 1 & & & & 1 & 6 & $10 \%$ & 100.0 \\
\hline Kaiserslautern & & & & & & & & & 3 & & 3 & $5 \%$ & 25.0 \\
\hline Hamburg & 1 & & & & & & 1 & & & & 2 & $3 \%$ & 11.1 \\
\hline Schalke 04 & & 2 & & & & 2 & & & & & 4 & $7 \%$ & 44.4 \\
\hline Bayer Leverkusen & & & 1 & & 2 & & 2 & 2 & 1 & 2 & 10 & $17 \%$ & 277.8 \\
\hline Stuttgart & & & & 2 & & & & & & & 2 & $3 \%$ & 11.1 \\
\hline Hertha Berlin & & & & & & & 1 & & & 1 & $2 \%$ & 2.8 & \\
\hline
\end{tabular}

\begin{tabular}{|c|c|c|c|c|c|c|c|c|c|c|c|c|c|c|}
\hline FRANCE & 2005 & 2004 & 2003 & 2002 & 2001 & 2000 & 1999 & 1998 & 1997 & 1996 & TOTAL & $\%$ & $\mathrm{HHI}$ & $\%$ HHI MAX \\
\hline O. Lyonnais & 3 & 3 & 3 & 3 & 3 & 2 & 1 & 1 & & & 19 & $32 \%$ & 1002.8 & \\
\hline Monaco & & 1 & 1 & 2 & & & 3 & & 1 & 3 & 11 & $18 \%$ & 336.1 & \\
\hline Nantes & & & & & & 3 & & & & 1 & 4 & $7 \%$ & 44.4 & \\
\hline Bordeaux & 2 & & & & & & & 3 & & & 5 & $8 \%$ & 69.4 & \\
\hline Lens & & & & & 2 & & & & 3 & & 5 & $8 \%$ & 69.4 & \\
\hline Lille & 1 & 2 & & & & 1 & & & & & 4 & $7 \%$ & 44.4 & \\
\hline Paris S.Germain & & & 2 & & & & 2 & & & 2 & 6 & $10 \%$ & 100.0 & \\
\hline Marseille & & & & 1 & & & & 2 & & & 3 & $5 \%$ & 25.0 & \\
\hline Auxerre & & & & & 1 & & & & & & 1 & $2 \%$ & 2.8 & \\
\hline Metz & & & & & & & & & 2 & & 2 & $3 \%$ & 11.1 & \\
\hline & & & & & & & & & & TOTAL & 60 & $100 \%$ & 1705.4 & $44 \%$ \\
\hline
\end{tabular}

\section{b. 2 Grouped Table}


The table below groups the results shown above in maximum unbalance order, from the long-term dominance viewpoint. Thus, the English Championship, over the past ten years, has the highest unbalance index, represented by the concentration of the same teams in the first three positions in the final standing.

c. 2 Grouped Table
\begin{tabular}{|l|c|}
\hline COUNTRY & $\%$ HHI MAX \\
\hline \hline England & $71 \%$ \\
\hline Germany & $63 \%$ \\
\hline Italy & $59 \%$ \\
\hline Spain & $53 \%$ \\
\hline France & $44 \%$ \\
\hline Brazil & $26 \%$ \\
\hline
\end{tabular}

\section{CONCLUSIONS AND RECOMMENDATIONS}

In order to avoid dominance by some teams, and the consequent bankruptcy of others, thus bringing about serious losses to a very profitable business such as the football industry, the balance of forces among the teams competing in the Brazilian championship should be pursued, in spite of the data favoring Brazil, as presented in the table grouped in the results of this paper. By comparing the levels of competitiveness between the Brazilian championship and the championships of the five biggest world football centers (England, Spain, Germany, France and Italy), and by interpreting the results, it can be inferred that:

1. The change in championship model as adopted by the teams in Brazil in 2003, which involves the point system format with options for classification to other football cups, has been leveraging the balance amongst the competing teams;

2. Repatriating high-renowned veteran players, on moderate-cost wages, represents an attempt in Brazil to improve the quality of each match. This factor (the quality of the match) is one of the three most important factors, along with result uncertainty and unpredictability and team success, in order to keep the end customers, the followers, in the stadiums.

These arrangements are making the matches in Brazilian football less predictable and more attracting, thus bringing more fans to the stadiums and increasing the number of viewers of the matches broadcasted on TV, consequently 
increasing the revenue of the football industry, which comprises the sales of merchandise; consulting, especially sports medicine consulting; and the sports services, like the matches and sports activities provided for the population as a whole.

On the other hand, a recommendation based upon this study should be made in order to enhance the financial balance and the balance of forces amongst the teams vying in the Brazilian championship:

Selling tickets for the championship matches in advance, by means of payment booklets that allow for an easier way for the stadium-goers to pay for their tickets, also represents an example provided by the main European championships of converting emotional relationship into commercial relationship, which should be followed in Brazil since the Brazilian demand does not seem to be as inflexible regarding ticket prices as verified by Szymansky and Kuypers (1999) in European football.

\section{REFERENCES}

BIKKER, J. \& K. HAAF (2001) Measures of Competition and concentration: A review of the literature. De Nederlansche Bank, Amsterdan, NL.

BIKKER, J. \& K. HAAF (2002) Competition, concentration and their relationship: An empirical analysis of the banking industry. Journal of Banking \& Finance, v. 26, p. 2191-2214.

BOAVENTURA, J. M. G.; FISCHMANN, A. A. Estudo dos Conceitos sobre o conteúdo da estratégia: uma ilustração no campo da tecnologia da informação. FEA, USP

CHAMBERLIN, E, H.(1933) The Theory of Monopolistic Competition. Cambridge, Mass, Harvard University

CHRISTENSEN, K, H. (1999) Estratégia Corporativa: Gerenciando um Conjunto de Negócios. In Fahey \& Randall. MBA Curso Prático de Estratégia.

CHETTY, S.; HUNT, C.; COLIN (2004) A Strategic Approach to Globalization: A traditional versus a "Born Global" Aproach. Journal of International Marketing. v.12, n.1, p. $57-81$.

FRASER, J.; OPPENHEIM, J. (1997) What's new about globalization? Mckinsey Quartely, v. 2, p. 168-179

JOHNSON, G; SCHOLES, K (1999) Exploring Corporate Strategy: Text and Cases. 5th Ed. N. York, Prentice - Hall.

Levitt, T (1983) The Globalization of markets. Harvard Business Review, Jun, p. 92102 
HITT, M.; IRELAND, D.; HOSKISSON, R. E. (2003) Administração Estratégica: competitividade e globalização. São Paulo, Pioneira Thompson

HOFER, C. W.; SCHENDEL, D. (1978) Strategy Formulation: Analytical Concepts. Saint Paul: West Publishing Co.

MINTZBERG, H.; QUINN, J. (2001) O Processo da Estratégia. 3 ed. Porto Alegre: Bookman.

MINTZBERG, H.; AHLSTRAND, B. \& LAMPEL, J. (2000) Safári de Estratégia. Porto Alegre: Bookman.

Relatório Final do Plano de Modernização do Futebol Brasileiro. R.Janeiro : FGV e CBF, 2000.

ROBINSON, J. (1933) The Economics of Imperfect Competition. Londres, Macmillan Press.

SCHUMPETER, J. (1911). Teoria do Desenvolvimento Econômico. Trad.port. S.Paulo: Ed. Abril Cultural, col. "Os Economistas", 1982.

SCHUMPETER, J. (1942). Capitalismo, Socialismo e Democracia. Trad, port. Rio de Janeiro: Zahar Ed, 1984.

SHY, O (1995) Industrial Organization. Cambridge MA: Mit Press

SRAFFA, P. (1926) The Laws of Rreturns under Competitive Condition. Economic Journal, v. 36, n. 2, p. 535-50

TACHIZAWA, T. Metodologia de pesquisa aplicada à administração: a internet como instrumento de pesquisa. Rio de Janeiro : Pontal, 2002.

VERGARA, S. Projetos e relatórios de pesquisa em administração. 5a edição, São Paulo: Ed. Atlas, 2004. 